\title{
Research Observation: Chemical repellants to reduce grazing intensity on reclaimed sites
}

\author{
TERRANCE J. OSKO, ROBERT T. HARDIN, AND BRUCE A. YOUNG
}

\begin{abstract}
Osko is graduate student and Hardin is professor of biometrics, Department of Animal Science, University of Alberta, Edmonton, Alberta, T6G 2P5. Young is professor and Chair, Department of Animal Production, Gatton College, University of Queensland, Lawes, $Q L D$ 4343, Australia. At the time of the research, Osko was an undergraduate student in the Faculty of Agriculture and Forestry, University of Alberta, and Young was professor of animal physiology, Department of Animal Science, University of Alberta.
\end{abstract}

\begin{abstract}
Revegetation of disturbed rangelands in western Canada is severely impeded by cattle grazing. Fencing to protect emergent vegetation is costly and restricts animal movement. Chemically repelling cattle from emergent vegetation may provide a convenient and economical alternative to fencing. This study determined whether certain repellents could reduce grazing intensity on vegetation to which they were applied compared to untreated vegetation. Canopy measurements were used to compare grazing intensity. Three trials were conducted on reclaimed land within the Aspen Parkland region of central Alberta. Time since reclamation was over 10 years in Trial A, 2 years in Trial B, and 3 weeks in Trial C. Pregnant mares' urine, Hinder (150 $\mathrm{mg} \mathrm{m}^{-1}$ ammonium soaps), Skoot ${ }^{\star 120} \mathrm{mg} \mathrm{ml}^{-1}$ tetramethylthiuram disulfide), and Deer-A way Big Game Repellent ${ }^{\circledast}$ (37\% putrescent egg solids) were evaluated. Two concentrations of each repellent were sprayed onto $1 \times 3-m$ treatment plots randomized within blocks replicated 4 to 6 times. Plot canopies were measured either by gently resting a sheet of plastic laminate over the canopy, or by lowering a sliding bar attached perpendicularly to a meter stick until it contacted the uppermost leaves of the canopy, and recording the height of the sheet or bar above the soil surface. Canopies of plots treated with Big Game Repellent were taller than control plot canopies on each measurement date in all trials, indicating grazing was reduced. Big Game Repellent ${ }^{\circledR}$ plots were also generally taller than plots treated with other repellents. Canopies of plots treated with pregnant mares' urine, Hinder ${ }^{\otimes}$, and Skoot ${ }^{\circledR}$ generally did not differ from control plots, nor did they differ from each other in any trial. Low repellent concentrations did not reduce grazing in any trial, but high concentrations reduced grazing in all trials. Repellent effectiveness was not permanent since all canopy measurements became shorter with time. Big Game Repellent ${ }^{\bullet}$ was effective in reducing grazing intensity by cattle, but practical use of repellents for grazing management requires further investigation.
\end{abstract}

Key Words: pipelines, reclamation, revegetation, livestock, forage selection, palatability, preference

Mention of a trade mark or proprietary product does not constitute a guarantee or warranty of this product by the University of Alberta and does not imply its approval to the exclusion of other products that may also be suitable.

The authors wish to acknowledge the Public Lands Division (Red Deer), Alberta Forestry Lands and Wildlife for providing resources for the study, Bob Valentine for donation of pregnant mare's urine, and Stancly Conn, John Duda, and John Frere for allowing access to their grazing leases. The financial support of the Natural Sciences and Engineering Resea rch Council of Canada is greatly appreciated. Gratitude is also expressed to Jack Francis for technical assistance, Ray Weingardt for statistical advice, and Anne Naeth and an anonymous reviewer for editorial comments.

Manuscript accepted 1 Mar. 1993
Industrial disturbances such as pipeline and well-site installations are common on western Canadian rangelands. New growth, particularly of introduced species, on reclaimed pipelines and wellsites is a powerful attractant to grazing animals (Hardy Associates (1978) Ltd. 1983, Naeth and Bailey 1984, Naeth 1985). Overutilization because of preferential grazing of these areas severely impedes revegetation efforts (Naeth 1985). Commonly, access by grazing animals to areas where grazing is undesired is restricted by exclosure fences. Fencing of pipelines is costly. The temporary requirement for protection necessitates dismantling the fences once permanent vegetation is re-established. Fencing of pipelines is inconvenient to livestock producers because they restrict animal movement to point resources such as water. An economical alternative to fencing which restricts utilization but not access, would be desirable.

Disturbances could be reseeded with mixtures containing unpalatable species (Naeth 1985). This would discourage utilization and establish permanent cover more rapidly. However, this option reduces available forage for grazing. Further reductions in available forage will occur should the new vegetation invade nondisturbed areas. A temporary solution, which may achieve the desired goal of protection from grazing, would be to apply unpalatable substances or repellents to reseeded vegetation.

Unpleasant tastes are associated with odors very rapidly by grazing animals (Müller-Schwarze 1991). Malodorous compounds derived from anti-feedants of plants might make useful repellents. Compounds derived from predator odors could potentially be used for repellants (Müller-Schwarze 1991) as could animal excreta or leachates of excreta. Marten (1978) reported that grazing dairy cattle refused brome (Bromus spp.) and reed canary grass (Phalaris arundinacea L.) growing over areas dressed with cow, sheep, or turkey manures, but readily consumed the same vegetation when it was harvested and offered fresh in bunks. When fresh dung was placed beneath mesh-bottomed bunks, dairy heifers spent significantly less time at these bunks and consumed less forage from them. Engle and Schimmel (1984) attempted to discourage cattle use of subirrigated lowlands using Deer-Away Big Game Repellent ${ }^{\otimes}$ (37\% putrescent egg solids). These authors were unable to show that cow chip counts differed on treated sites from counts on control sites. However, cow chip counts merely indicate occupation by cattle (Engle and Schimmel 1984), not necessarily the intensity of grazing associated with that occupation.

The objective of our study was to determine whether application of repellents to pasture vegetation would reduce grazing intensity by cattle relative to similar vegetation not treated with repellents 
Table 1. Summary of attributes of reclaimed areas, treatments, and measurements within study sites for Trials, A, B, and C.

\begin{tabular}{|c|c|c|c|}
\hline Attribute & Site A & Site B & Site C \\
\hline $\begin{array}{l}\text { Area, ha } \\
\text { Total (Reclaimed) }\end{array}$ & $73(20)$ & $58(6)$ & $66(0.25)$ \\
\hline $\begin{array}{l}\text { Topography } \\
\text { (Ag Canada 1987) }\end{array}$ & Level to Undulating & Hummocky & Hummocky \\
\hline Time Since Reclaimed & 10 years & 2 years & 3 weeks \\
\hline Vegetation on Reclaimed Area & $\begin{array}{l}\text { Poa pratensis } \mathrm{L} . \\
\text { Trifolium repens } \mathrm{L} \text {. }\end{array}$ & $\begin{array}{l}\text { Phleum pratense } \mathrm{L} . \\
\text { Trifolium hybridum } \mathrm{L} \text {. }\end{array}$ & $\begin{array}{l}\text { Agropyron pectiniforme R. \& S. } \\
\text { A. trachycaulum (Link) Malte } \\
\text { Bromus inermis Leyss. } \\
\text { Dactylis glomerata L. } \\
\text { Lolium perenne L. } \\
\text { Medicago spp. } \\
\text { Phleum pratense L. } \\
\text { Trifolium repens L. }\end{array}$ \\
\hline Tillers $\mathrm{m}^{-2}$ & 4900 & 1050 & 172 \\
\hline Trial Duration, days & 73 & 33 & 40 \\
\hline Date Repellents Applied & 30 May & 9 Jun & $19 \mathrm{Jul}$ \\
\hline No. of Treatment Blocks & 6 & 6 & 4 \\
\hline Grazing Began & 31 May & $10 \mathrm{Jun}$ & $19 \mathrm{Jul}$ \\
\hline $\begin{array}{l}\text { Stocking Rate, AUM ha } \\
\text { Recommended (Actual) }\end{array}$ & $0.74(0.90)$ & $0.71(0.76)$ & $0.74(1.21)$ \\
\hline $\begin{array}{l}\text { Measurement Dates } \\
\text { (Precip., mm, in interval) }\end{array}$ & $\begin{array}{l}15 \text { Jun (15.7) } \\
29 \text { Jun (57.7) } \\
27 \text { Jul (62.5) } \\
10 \text { Aug (28.8) }\end{array}$ & $\begin{array}{l}19 \operatorname{Jun}(28.0) \\
28 \mathrm{Jun}(45.2) \\
12 \mathrm{Jul}(58.8)\end{array}$ & $\begin{array}{l}11 \text { Aug (57.0) } \\
21 \text { Aug (38.8) } \\
28 \text { Aug (17.6) }\end{array}$ \\
\hline
\end{tabular}

using comparisons of canopy measurements among treatments as indicators of grazing intensity.

\section{Materials and Methods}

\section{Study Area}

Three trials (A, B, and C) were completed between 30 May and 28 August 1989 on 3 sites within the Aspen Parkland region (Strong and Leggat 1981) of central Alberta. The Aspen Parkland region is an ecotone between the Boreal Forest to the north and the Northern Mixed Prairie to the south. Mean annual precipitation in the region is $450 \mathrm{~mm}, 40 \%$ of which falls in the winter as snow (Strong and Leggat 1981).

All 3 trials were conducted on rangelands consisting of small natural openings of 5 ha or less within groves dominated by aspen poplar (Populus tremuloides Michx.). Various grasses including slender wheatgrass (Agropyron trachycaulum (Link) Malte), western wheatgrass (Agropyron smithii Rydb.), western porcupine grass (Stipu curtiseta (Hitchc.) Barkworth), awned wheatgrass (Agropyron subsecundum (Link.) Michx.), Junegrass (Koeleria macrantha (Ledeb.) Schult.), and plains rough fescue (Festuca hallii (Vasey) Piper.) occupied these openings. Shrubs such as western snowberry (Symphoricarpos occidentalis Hook.), shrubby cinquefoil (Potentilla fruticosa L.), and willows (Salix spp.) were also present, as were forbs such as fringed pasture sage (Artemisia frigida Willd.), prairie sage (Artemisia ludoviciana Nutt.), and common yarrow (Achillea millefolium L.). Wild rose (Rosa spp.), willows, saskatoon (Amelanchier alnifolia (Nutt.) (Nutt), Canadian buffaloberry (Shepherdia canadensis (L.) Nutt.), northern bedstraw (Galium boreale L.), marsh reed grass (Calamagrostis canadensis (Michx) Beauv.), and hairy wild rye (Elymus innovatus Beal) made up the understory in the aspen groves. Attributes of reclaimed areas - dates of spraying, grazing, and canopy measurements-and other study details are summarized in Table 1.

\section{Repellents}

Four potential cattle repellents were selected based upon their availability. Pregnant mares' urine, which is collected commer- cially to extract hormones for manufacturing of oral contraceptives, was evaluated because grazing animals are known to avoid areas of pasture soiled with animal excreta (Marten 1978) and because large volumes are available. No analysis of pregnant mares' urine was conducted and no information was available on its use as a repellent. Hinder (150 $\mathrm{mg} \mathrm{ml}^{-1}$ ammonium soaps), Skoot ${ }^{\odot}\left(120 \mathrm{mg} \mathrm{ml}^{-1}\right.$ tetramethylthiuram disulfide), and Big Game Pellent ${ }^{\circledR}$, were registered under the Canadian Pest Control Products Act for use in repelling wildlife species (Alberta Environment 1990).

Manufacturers of Hinder ${ }^{\circledR}$ recommended spraying a $7.5 \mathrm{mg}$ ai $\mathrm{ml}^{-1}$ solution of Hinder ${ }^{\circledR}$ and water every 4 weeks for protecting forage crops from deer. More frequent applications were recommended in the event of precipitation between applications. Manufacturers of Skoot claimed that 1 application of a $50 \%$ dilution of Skoot ${ }^{3}$ with water in the late fall would protect trees and shrubs from browsing deer for the entire dormant season. Manufacturers of Big Game Repellent recommended spraying a $47.1 \mathrm{mg} \mathrm{ai} \mathrm{ml}^{-1}$ solution of the repellent and water every 6 to 8 weeks to protect conifer seedlings and ornamental shrubs from browsing deer. Applications under wet conditions were not recommended.

\section{Treatments}

Repellent effectiveness in reducing grazing intensity was inferred from estimates of canopy height, assuming plots grazed most intensively would have the shortest canopies. In Trials A and B, canopy height was estimated by gently resting a $61 \times 61-\mathrm{cm} \times$ 3-plot. Plots were randomized within blocks and spaced 1-m apart. Blocks were replicated 6 times in Trials $A$ and B, but only 4 times in Trial $C$ because of size constraints of the reclaimed area within which blocks were located. Blocks were arranged within each pasture to maximize homogeneity of vegetation and micro-relief within them. Minimum distances between blocks were at least $10 \mathrm{~m}$ in all trials. The manufacturers of Hinder recommended spraying the repellent at a volume of $450-950$ liters ha ${ }^{-1}$. Neither of the other registered repellents gave recommended spray volumes. Therefore, each solution was applied to its respective plot at a volume of 1,000 
Table 2. Comparison of means of canopy height estimates for controls and repellents by date within 3 trials. Time since reclamation and reseeding prior to treatment applications were 10 years in Trial A, 2 years in Trial B, and 3 weeks in Trial C.

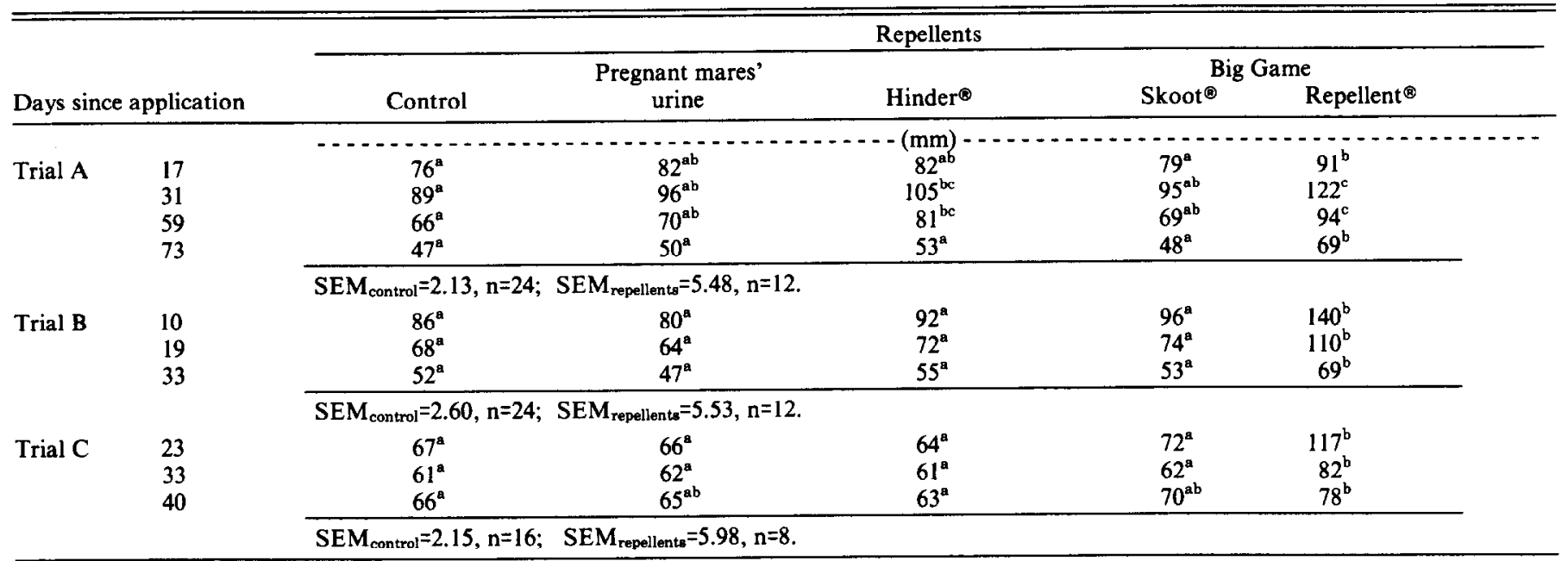

Values followed with the same superscript within dates do not differ $(P<0.05 \%)$.

liters $\mathrm{ha}^{-1}$ in order to ensure adequate wetting of plant material. Solutions were applied using hand held, 1-liter capacity, pressurized sprayers. Separate sprayers were used for each repellent and for water controls to avoid cross contamination. Areas adjacent to each plot were protected from drifting spray by sheets of polyethylene film. Repellents were applied at the beginning of each trial and were not reapplied in order to assess how long differences in canopy measurements remained as a result of a single application.

\section{Measurements}

Repellent effectiveness in reducing grazing intensity was inferred from estimates of canopy height, assuming plots grazed most intensively would have the shortest canopies. In Trials A and B, canopy height was estimated by gently resting a $61 \times 61 \mathrm{~cm} \times$ $1-\mathrm{mm}$ sheet of plastic laminate, weighing $567 \mathrm{~g}$, on the plant canopy over the center of each quadrant of each plot. The height of the sheet above the soil surface was measured at the mid-point of each side of the sheet (McNaughton 1984). Low stature and sparseness of new vegetation in Trial $\mathbf{C}$ necessitated an alternative measurement system. Measurements were obtained using a sliding cross-bar ruler. The device consisted of a $46 \times 5 \times 1-\mathrm{cm}$ bar, cut from oriented paper-strand board, fastened perpendicularly to a meter stick to form a cross. The bar was attached loosely so that the height of the bar could be adjusted by sliding it along the meter stick, which was inserted vertically into the grass sward. The bar was lowered until the uppermost leaves in the canopy touched the bottom of the bar. Leaf height was read directly from the meter stick. Sixteen measurements were taken at $33-\mathrm{cm}$ intervals along a grid within each plot. Because canopy measurements were used to compare relative differences within trials only, it was not necessary for the 2 techniques to be compared.

\section{Statistical Analysis}

All comparisons were made within trials only. The model was a 4 $\times 2$ factorial with a single control (Winer 1962) arranged in randomized blocks. Four zero level treatments within a given block were pooled to estimate a single control for that block. The $4 \times 2$ factorial model was used instead of a $4 \times 3$ model because inclusion of zero chemical treatments in the factorial would reduce apparent differences among chemicals since no differences would be expected among zero chemical treatments.

Orthogonal contrasts were used to evaluate differences among chemicals, between individual chemicals and controls, between repellent concentrations, and between these concentrations and controls. Contrasts were also used to determine the significance of chemical $\times$ concentration interactions. Block $\times$ treatment was used as the error term to test differences among these main effects and their interactions at the $0.05 \%$ level of probability. Serial measurements over time were analyzed as repeated measures (Milliken and Johnson 1984) using the residual error term to test date and treatment $X$ date interactions. All analyses were completed using the general linear models procedure of the Statistical Analysis System (SAS 1989).

\section{Results and Discussion}

Significant differences among chemicals were observed in all 3 trials. Levels differed in Trials B and C, but not in A. There were no significant chemical $\times$ level interactions. The effect of measurement date was significant in all 3 trials, as were chemical $X$ date interactions. Concentration $\times$ date interactions were not significant in any of the trials.

Canopies of plots treated with Big Game Repellent ${ }^{\circledR}$ were taller than control plot canopies on each measurement date in all 3 trials (Table 2). Canopy height of plots treated with pregnant mares' urine, Hinder ${ }^{\otimes}$, and Skoot ${ }^{\ominus}$ did not differ from control plot heights in Trials B and C. Canopies of Hinder treated plots were taller than control plot canopies on 2 occasions in Trial A (Table 2). Canopies of plots treated with Big Game Repellent ${ }^{\circledR}$ were generally taller than canopies of plots treated with pregnant mares' urine, Hinder ${ }^{-}$, and Skoot in all trials. Measurements of pregnant mares' urine, Hinder ${ }^{\circ}$, and Skoot ${ }^{\circ}$ in all trials. Measurements of pregnant mares' urine, Hinder ${ }^{\ominus}$, and Skoot ${ }^{\ominus}$ treated plots did not differ from each other in any trial (Table 2). Except for an increase between the first and second measurement dates in Trial A, all canopies became shorter with time in each of the trials (Table 2). Canopy heights on low concentration treatments did not differ from heights on control treatments in any trial (Table 3), but canopy heights on high concentration treatments were taller than on controls in all 3 trials. Canopies on high concentration treatments were taller than canopies on low concentration treatments in Trials B and C, but did not differ in Trial A (Table 3).

Big Game Repellent ${ }^{-}$was apparently effective in reducing grazing by cattle in all 3 trials and would therefore be expected to reduce grazing of treated vegetation under a variety of site conditions. The experiments were not designed to allow comparisons among trials, therefore it is unknown whether any interactions occurred between the repellents and specific site conditions which may have affected repellent performance. Because repellents were similarly ranked in all trials, site differences in species composition, 
Table 3. Comparisons of means of canopy height estimates for 2 repellent concentrations ${ }^{1}$ within 3 trials. Time since reclamation and reseeding prior to treatment applications were 10 years in Trial A, 2 years in Trial $B$, and 3 weeks in Trial $C$.

\begin{tabular}{|c|c|c|c|c|}
\hline & \multicolumn{4}{|c|}{ Repellent concentration } \\
\hline & Control & Low & High & SEM \\
\hline Trial A & $70^{\mathrm{a}}$ & $77^{\mathrm{ab}}$ & $84^{\mathrm{b}}$ & 3.71 \\
\hline Trial B & $69^{\mathrm{a}}$ & $74^{\mathrm{a}}$ & $85^{\mathrm{b}}$ & 3.69 \\
\hline Trial C & $64^{a}$ & $65^{\mathrm{a}}$ & $79^{\mathrm{b}}$ & 3.99 \\
\hline
\end{tabular}

IRepellent concentrations were: $25 \%$ and $100 \%, 7.5$ and $30 \mathrm{mg} \mathrm{ai} \mathrm{ml}^{-1}, 15$ and $60 \mathrm{mg}$ ai $\mathrm{ml}^{-1}$, and 9.8 and $39.3 \mathrm{mg} \mathrm{ai} \mathrm{ml}^{-1}$, respectively, for pregnant mares' urine, Hinder Skoot ${ }^{\star}$, and Big Game Repellent ${ }^{\star}$.

Values followed by the same superscript within dates do not differ ( $P<0.05 \%) ; n=96$, 72 , and 48 for Trials $A, B$, and C, respectively.

tiller density, ambient air temperature, and precipitation did not appear to affect relative repellent performance in this study.

It is uncertain how long Big Game Repellent actively repelled cattle from treated vegetation, but since canopies of plots treated with it were always taller than control plot canopies, cattle were directly averted by the chemical at least initially. Vegetation within

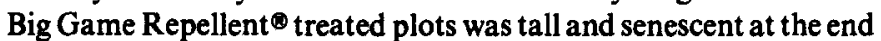
of Trial A, whereas plants within other treatment plots were shorter and still vegetative. Repellent effectiveness was apparently not permanent because canopies within Big Game Repellent $₫$ treated plots became shorter with time. This may affect when repellents should be applied for maximum benefit. Areas to be protected should be treated before cattle are released onto pasture and animals should be exposed to these areas as soon after treatment as possible in order to facilitate the establishment of desired grazing patterns. It may be more difficult to change grazing patterns of cattle with repellents once such patterns have been established, as Engle and Schimmel (1984) had previously noted.

Big Game Repellent ${ }^{\circ}$ reduced grazing intensity but did not eliminate grazing entirely. Therefore, Big Game Repellent ${ }^{\circledR}$ appears to be less effective than exclusion by fencing in protecting vegetation from grazing. Nevertheless, increases in residual biomass caused by reduced grazing of treated plots may sufficiently improve photosynthetic capacity such that adequate root and crown reserves are accumulated for winter survival (Parsons 1988). Re-establishment of new vegetation could thereby be facilitated with applications of Big Game Repellent to emergent vegetation.

The expression of selection behavior is contingent upon the availability of choices (Heady 1964, Skiles 1984, Bush 1989). The key to reducing forage consumption using chemical stimuli depends on the capacity of a repellent to reduce the acceptability of treated forage relative to available alternatives. It may be relatively easy to avert animals from small patches using repellents because there are abundant alternative patches available within a community. Aversion from an entire community may be much more difficult since the number of alternative communities within a landscape would be far fewer. In other words, the apparent homogeneity of very large treatment areas and possible odor habituation within them (Müller-Schwarze 1991) may reduce repellent effectiveness.

Investigation of the mechanisms by which repellents work may provide clues for the development of more effective repellents. Suitably effective repellents could potentially be used for training animals to avoid geographical locations within pastures. Aversion learning has proven successful in training grazing animals to avoid certain foods (Provenza and Balph 1987; Burrit and Provenza 1989a, 1989b, 1990). Since cattle have accurate spatial memory regarding locations of food abundance (Bailey et al. 1989), perhaps aversion to specific areas can be learned if cattle can associate geographical locations with unpalatable forage. Big Game Repellent ${ }^{\circledR}$ was effective in reducing grazing intensity by cattle in this study, however practical use of repellents for grazing management requires further investigation.

\section{Literature Cited}

Agriculture Canada Expert Committee on Soil Survey. 1987. The Canadian system of soil classification. 2nd ed. Agr. Can. Publ. 1646.

Alberta Environment. 1990. Pesticide quick reference. Alberta Environment, Wastes and Chemicals Division, Pesticide Management Branch. Calgary, Alberta.

Bailey, D.W., L.R. Rittenhouse, R.H. Hart, D.M. Swift, and R.W. Richards. 1989. Association of relative food availabilities and locations by cattle. J. Range Manage. 42:480-482.

Burritt, E.A., and F.D. Provenza. 1989a. Food aversion learning: a bility of lambs to distinguish safe from harmful foods. J. Anim. Sci. 67:1732-1739.

Burritt, E.A., and F.D. Provenza. 1989b. Food aversion learning: conditioning lambs to avoid a palatable shrub (Cercocarpus montanensis) J. Anim. Sci. 67:650-653.

Burritt, E.A., and F.D. Provenza. 1990. Food aversion learning in sheep: Persistence of conditioned taste aversions to palatable shrubs (Cercocarpus montanensis and Amelanchier alnifolia). J.Anim. Sci. 68:1003-1007.

Bush, R.S. 1989. Preference among grains expressed by young holstein calves. Can. J. Anim. Sci. 69:1099-1103.

Engle, D.M., and J.G. Schimmel. 1984. Evaluation of pipeline reclamation practices on agricultural lands in Alberta. RRTAC \#83-3, prepared for Reclamation Research Technical Advisory Committee of Alberta Energy and Natural Resources.

Heady, H.F. 1964. Palatability of herbage and animal preference. J. Range Manage. 17:76-82.

Marten, G.C. 1978. The animal-plant complex in forage palatability phenomena. J. Anim. Sci. 46:1470-1477.

McNaughton, S.J. 1984. Grazing lawns: animals in herds, plant form, and coevolution. Amer. Natur. 124:863-886.

Milliken, G.A., and D.E. Johnson. 1984. Analysis of messy data. Van Nostrand Reinhold Co., N.Y.

Müller-Schwarze, D. 1991. The chemical ecology of ungulates. Appl. Anim. Behav. Sci. 29:389-402.

Naeth, M.A. 1985. Ecosystem reconstruction and stabilization following pipeline construction through solonetzic rangeland in southern Alberta. M.Sc. Thesis, Univ. Alberta. Edmonton.

Naeth, M.A., and A.W. Balley. 1984. Effects of time and grazing regime on revegetation of native range after pipeline construction, item 20 . In: Proc. 9th Annu. Meeting of Canadian Land Reclamation Assoc., Calgary, Alberta.

Parsons, A.J. 1988. The effects of season and management on grass swards, p. 129-178. In: Michael B. Jones and Alec Lazenby (eds), The grass crop. Chapman and Hall, N.Y.

Provenza, F.D., and D.F. Balph. 1987. Diet learning by domestic ruminants: theory, evidence, and practical implications. Appl. Anim. Behav. Sci. 18:211-232.

SAS Institute, Inc. 1989. SAS user's guide: statistics, 1989 edition. SAS institute, Inc., Cary, N.C.

Skiles, J.W. 1984. A review of animal preference, p. 153-213. In: NRC/NAS, Developing strategies for rangeland management. Westview Press, Boulder, Colo.

Strong, W.L., and K.R. Leggat. 1981. Ecoregions of Alberta. ENR Tech. Rep. T/4. Alberta Energy and Natural Resources, Edmonton.

Winer, B.J. 1962. Statistical principles in experimental design. McGrawHill Book Co. Inc., Toronto. 